The Brock Review Volume 12 No. 1 (2011)

(C) Brock University

\title{
When the Species Comes
}

Susan Benston

When the species comes,

our cortisols will rise,

our vessels clench, hearts hammer

in the clutch of epinephrine,

hamstrings bunch with that primal choice:

the fight, the flight-

we shall be poised

for the starting gun,

the leap into unsought destiny.

A few of us will genuflect,

prostrate as though before a risen god-

though not the beloved, thundering, vengeful lord

made in our image; here is grace

of another order...

genus...species...

this is huge, remote,

an astounding riff on our reptile-mammal frame,

with cephalic bulb, ribbed thorax, four extremities, 
and a hint of peculiar function

in that strange arrangement of digits-here is a skewed sublime,

ranked immeasurably before us,

eyeing us with unambiguous eyes.

When the species comes

we will turn our gaze amongst ourselves

in desperate solidarity,

each seeking resolution

or rebuke: "You err: no hulking masses have arrived

to steal our birthright. This is earth,

which nursed us into being; this is earth,

our sovereign state-

See where our silos rise, laden with grain;

where cities facet the sky

and nuclear reactors squat, thrillingly mundane

with boundless power. See how they spew-how factories spew

in glad abundance;

how delicate bottles of vaccine

spin by the millions down their labyrinthine channels

into their cartons;

how the cattle climb,

numberless,

up through symmetrical walkways 
into their slaughterhouse;

how feathers fly, euphoric,

up from the forty-thousand-occupancy barns,

out of the cages high

on wind-sped eighteen-wheelers;

how the seals bleed by the thousands

on the ice. - See the profusion,

the seething, glittering saturnalia of our reign.

No one decreed a terminus;

no one can countenance this thing."

When the species comes

we will wake

to stricter circumstances,

all of us constrained.

The few will be in zoos, scratching their beards;

others scrambling headlong through walled parks

riven by unseen missiles;

others languishing in coffin-size stalls

and lightless crates;

countless others jostling, ten to a cage,

branded, tagged, with genitals excised.

When the species comes, 
millions of us will live our lives

in chilled antisepsis,

waiting for fascinated fists to lift us forth

and lay us wide;

for curious hands

to shock us and submerge us,

dexterously injure us,

plague us with innumerable blights

and gauge our pain.

Our sacrifice will benefit the new, sovereign breed.

We will not suffer

in vain. 